\title{
The Effect of Fixed Exchange Rates on Monetary Policy of the GCC Countries
}

\author{
Ashraf Nakibullah $^{1}$ \\ ${ }^{1}$ Arab Open University, Bahrain Branch, Bahrain \\ Correspondence : Ashraf Nakibullah, Arab Open University-Bahrain, P.O. Box 18211, Bahrain.
}

Received: November 11, 2016

Accepted: December 5, 2016

Available online: December 7, 2016

doi:10.11114/aef.v4i2.2053

URL: http://dx.doi.org/10.11114/aef.v4i2.2053

\begin{abstract}
The GCC member countries have maintained fixed exchange rates against the US dollar for a long time now. These countries also allow liberal cross-border capital movements. Given these arrangements, they have theoretically given up the monetary independence according to the trilemma stating that countries with fixed exchange rates cannot pursue both domestic monetary independence and free capital mobility. This paper tests trilemma for the GCC member countries excluding Saudi Arabia and the UAE due to the unavailability of the pertinent interest rates data from these countries. Using the most recent quarterly data for the period 2004 to 2015, the general finding is that these countries still have some monetary independence. Results for Qatar indicate that they can maintain a full monetary autonomy if the circumstances make them to do so.
\end{abstract}

Keywords: capital controls, fixed exchange rates, trilemma, bounds testing technique

\section{Introduction}

Open economies with fixed exchange rates cannot pursue both domestic monetary autonomy and free capital mobility. That is, open economies face trilemma because out of the three objectives of fixed exchange rates, monetary autonomy, and free capital movement, countries can choose only two and have to decide which one is to give up. Recently researchers have extensively tested trilemma empirically (Frankel, Schmukler, and Serven, 2004, Klein and Shambaugh, 2015, Obstfeld, Shambaugh, and Taylor, 2004, Obstfeld, Shambaugh, and Taylor, 2005, Obstfeld, Shambaugh, and Taylor, 2010, and Shambaugh, 2004). Obstfeld et al., (2005) have argued that the clarity and simplicity of the trilemma have been disregarded by the policymakers probably due to the lack of empirical studies. Thus, they test the trilemma using mostly European countries covering more than 130 years of different eras (gold standard era, Bretton Woods era and post-Bretton Woods era). They find that pegging countries lose considerable monetary independence with the absence of capital controls. The Bretton Woods system collapsed in the early seventies because the exchange rate pegs and monetary independence were not feasible with the porous capital controls in the 1960s.

The standard open economy macroeconomics principles teach us that the effectiveness of monetary policy of an open economy depends on the exchange rates regime and the extent of capital controls. The Gulf Cooperation Council (GCC) member countries (Bahrain, Kuwait, Oman, Qatar, Saudi Arabia and the UAE) are very open economies measured by any definition of openness (Hasan and Nakibullah, 2015). For a long time now their exchange rates are fixed against the US dollar. The currencies of Bahrain, Qatar, Saudi Arabia and the UAE have been effectively pegged to the US dollar from 1980 whereas the currency of Oman has been officially fixed since 1986. Kuwait's currency has been pegged to an undisclosed basket of currencies where dollar is the dominating currency. The other relevant issue for their monetary policy is their extent of capital controls. The extent of the capital controls of the GCC countries is described as liberal (Fasano, 2003). Though the meaning of liberal capital control is not exactly defined or explained, it could be understood as partial or limited capital controls.

One can best say that the capital markets of the GCC countries are not completely open. Question remains whether with partial or limited capital controls these countries have enjoyed monetary autonomy. Klein and Shambaugh (2015) have argued and empirically established that countries cannot round the corners of the policy trilemma by partial capital control to establish full monetary policy autonomy. Countries with fixed exchange rate regime are not able to enjoy greater monetary autonomy with partial open accounts compared with full open capital accounts.

Abed, Erbas, and Gueromi (2003) argue that the prevailing exchange rates pegged with the absence of significant 
capital account restrictions for the GCC countries have narrowed the scope of monetary interventions. Hassan, Nakibullah, and Hassan (2013) provide evidence that capitals are not perfectly mobile for these countries and they have some room to maneuvering monetary policy. However, these authors neither explain nor address directly the meaning of monetary independence or autonomy. Some other authors have assumed that these countries lack monetary autonomy because of their liberal capital flows and fixed exchange rate regime (see, for examples, Fasano, 2003, and Nakibullah, 2011). They argue that monetary policy of these countries is essentially to manage liquidity by sterilizing the impact of international reserves on their monetary bases. International reserves fluctuate with oil price shocks and capital flows and they try to neutralize the impact on monetary bases so that their overall stated goal of price stability is maintained.

However, none of these papers empirically test the trilemma for the GCC countries or test the meaning of the monetary autonomy. Thus, the purpose of this paper is to test the trilemma for these countries. Following Frankel et al. (2004) and Obstfeld et al. (2005), this paper takes the observed short-term market interest rates as a measure of monetary policy and monetary independence meaning that the countries are able to set their own nominal interest rates.

Next section discusses the extent of capital controls in the GCC countries. Section 3 discusses empirical methodology to test trilemma and monetary autonomy. Section 4 discusses data and presents empirical results and section 5 concludes the paper.

\section{Extent of Capital Controls in GCC Countries}

Cross border capital movements and their controls play a vital role in the trilemma. Tight capital controls, in fact, can insulate the domestic interest rates from the base interest rates and in that case monetary autonomy can be achieved with fixed exchange rates. Yet such measures may not be desirable when the welfare of the country and its citizens are concerned. Klein (2012) discusses in details how countries benefit from free capital flows (inflows and outflows). Capital inflows to a country can increase the amount of productive capital to the country and at the same time would increase the return to investors from which capital has flowed out. International transactions allow both the domestic savers to smooth consumption by diversifying their portfolios and domestic producers to take risky projects. Technological and financial developments are also linked to the foreign direct investment such as building factories, stores, and financial subsidiaries.

Free capital flows across the borders usually promote economic growth, development, and economic welfare. However, the reality is that some sorts of capital controls exist literally in all economies including advanced economies though the overall control worldwide has been decreasing over the time 1970-2007 (Klein, 2012). In characterizing capital flows, Klein (2012) and Fernandez, Klein, Rebucci, Schindler and Uribe (2015) have classified countries as Open, Gate or Wall. Open countries essentially have no capital controls on any asset category. Wall countries (or long-standing capital controls as in China and India) have widespread capital controls across almost all categories of assets. Gate countries use capital control episodically. That is, as Klein $(2012$, p. 3) explains that "episodic capital controls open like gates during tranquil times, to enable an economy to benefit from international capital, but swing shut in the face of capital inflows that threaten to cause an unwanted appreciation or a destabilizing asset market boom." However, as mentioned above, there is hardly any country that has no capital control of any sort. Thus, empirical studies categorize open countries with capital controls less than $10 \%$ (or maximum $20 \%$ ) of their transaction subcategories and walls countries with capital controls more than 70\% (Klein 2012 and Fernandez et al. 2015). If any country does not fall in these categories becomes automatically gate country.

According to these classifications, Oman and Qatar are classified as open countries whereas Bahrain, Kuwait, Saudi Arabia and the U.A.E as gate countries (Fernandez et al., 2015). However, according to IMF's recent measures of capital controls there seems not much difference among the GCC countries (table 1). Among the measures are capital market (more than one year maturity), money market (one or less than one year maturity), and collective investment (mutual funds) securities, derivatives (include operations in rights, warrants, financial options and futures), commercial credits (linked with international trade transactions), guaranties, sureties, and financial back-up facilities (as a guarantee for independent financial operations), real estate transactions and direct investment. Table 1 shows the controls on transactions of the GCC countries taken from the recent IMF's Annual Report on Exchange Arrangements and Exchange Restrictions (AREAER). Table 1 shows Saudi Arabia followed by Kuwait and Qatar has restrictions on more categories of assets. All of them have common restrictions on capital market securities, direct investment, provision on commercial banks and other credit institutions and real estate transactions. However, the extent of capital controls within the measures must have been different so that Fernandez et al. (2015) have categorized Oman and Qatar as open countries (between $10-20 \%$ of control) and others as gate countries. The question is whether these partial capital controls have enabled them to pursue monetary autonomy. 
Table 1. Categories of controls on capital transactions

\begin{tabular}{|c|c|c|c|c|c|c|}
\hline Controls on: & Bahrain & Kuwait & Oman & Qatar & S. Arabia & UAE \\
\hline Capital market securities & $\bullet$ & - & - & - & - & $\bullet$ \\
\hline Money market securities & & - & & & - & \\
\hline Collective investment securities & & $\bullet$ & & & $\bullet$ & $\bullet$ \\
\hline Derivatives & $\bullet$ & $\bullet$ & • & • & $\bullet$ & \\
\hline Commercial Credits & & & & & $\bullet$ & \\
\hline Financial credits & & & & & - & \\
\hline Guarantees, sureties facilities & & & & & $\bullet$ & \\
\hline Direct investment & $\bullet$ & - & • & • & $\bullet$ & $\bullet$ \\
\hline Real estate transactions & - & - & - & - & - & - \\
\hline Personal capital transactions & & & & $\bullet$ & & \\
\hline \multicolumn{7}{|l|}{ Provisions specific to: } \\
\hline $\begin{array}{l}\text { Commercial banks and other } \\
\text { credit institutions }\end{array}$ & $\bullet$ & $\bullet$ & • & - & • & $\bullet$ \\
\hline Institutional investors & & & & $\bullet$ & $\bullet$ & \\
\hline
\end{tabular}

Source: AREAER, October 2014, IMF.

\section{Empirical Methodology}

Following Frankel et al. (2004), Obstfeld et al. (2004), and Shambaugh (2004), this paper takes the observed short-term nominal interest rates rather than monetary aggregates as the measure of monetary policy. Monetary autonomy can be measured by the movements in these rates relative to the base country interest rates. Interest rate targeting or manipulation generally has served the monetary policy strategy. Because interest rate is directly affected by monetary policy changes which imply that if it is not the main instrument of monetary policy, it would still serve as a monetary policy stance. Though some central banks focus on monetary aggregates, most central banks view short-term interest rate as their preferred policy instrument.

Free cross border capital mobility and fixed exchange rates imply that the nominal interest rate of the home country must be equal to the interest of the base country. If the nominal interest is not equal, the investment funds will flow where returns are higher till interest rate is equal. This means we should focus on nominal rather than real interest rate. Other reason to focus on nominal interest rate such as overnight money market rate or federal funds rate is generally the instrument of the central bank.

The (uncovered) interest parity condition for the GCC countries can be written as

$$
R_{i t}=R_{u s t}+s_{t+1}^{e}-s_{t}+\rho
$$

where $R_{i t}$ is the nominal interest rate of a GCC country $i$ at time $t, R_{u s t}$ is the nominal interest of the U.S., $s_{t+1}^{e}$ is the expected nominal exchange rate that will prevail in one year's time, and $\rho$ is the difference in risk (risk premium) between two countries. The GCC countries maintain a credible exchange rate which implies $S_{t+1}^{e}=S_{t}$. If the risk premium is very small or does not change with the change in interest rates, the nominal interest rate of a GCC country must be equal to the nominal interest rate of the US:

$$
R_{i t}=R_{U S t} \text {. }
$$

There are reasons, as explained by Obstfeld et al. (2004), to estimate equations in the difference form. Interest rates data are nonstationary (not shown here). If interest rates data are nonstationary or nearly so, regression in level forms may result in spurious correlation problem and differencing the data removes this problem. Estimating equation in difference form is also appropriate whether one is using small or large samples. If uncovered interest rate parity (1) holds then regression with large sample in level form would give the unitary slope coefficient regardless the home country exercises short-run interest-rate (monetary) independence. Thus, the monetary independence is tested using the specification

$$
\Delta R_{i t}=\alpha+\beta \Delta R_{U S t}+\eta_{i t}
$$

If the trilemma holds (that is, with perfect capital mobility and credible fixed exchange rate), we would expect $\beta=1$. In other words, if the risk premium is constant and the exchange rate is fixed, the home country cannot move its own interest leading to $\beta$ equal to 1 . Thus the estimated $\beta$ will be used as the measure of a GCC country's monetary independence and with $\beta=1$ the monetary independence will be nil. The estimated $\beta<1$ would imply that a GCC country uses its monetary autonomy to offset the US interest rate shocks.

We also use the cointegration technique of Pesaran, Shin, and Smith (2001) to test whether there is a significant long-run levels relationship between the GCC and the US interest rates. One of the advantages of their technique (known as the bound testing) is that we do not have to worry about the order of integration of the interest rates (variables). The error correction model for the interest rate based on the bound testing procedure can be specified as: 


$$
\Delta R_{i t}=\alpha_{0}+\alpha_{1} R_{i t-1}+\alpha_{2} R_{U S t-1}+\sum \gamma_{s}^{\prime} \Delta X_{t-s}+\eta_{i t}
$$

where $X_{t}=\left(R_{i t}, R_{U S t}\right)^{\prime}$. The null hypothesis of no long-run relation in the level of the variables is based on F-test and given by: $H_{0}: \alpha_{1}=\alpha_{2}=0$. Since the F-test has non-standard distributions, Pesaran et al. (2001) provide different critical values for $I(0)$ and $I(1)$ processes. If the calculated F-statistic falls above the upper bound critical value, the null hypothesis of no long-run relation is rejected.

Once it has been confirmed that the variables are related (cointegrated) in the long-run, the levels relationships and adjustment speed can be estimated using the following equation,

$$
\Delta R_{i t}=\theta\left(c+R_{i t-1}-b R_{U S t-1}\right)+\alpha+\beta \Delta R_{U S t}+\eta_{i t}
$$

where we can add lags of $\Delta R_{i t}$ and $\Delta R_{U S t}$ as necessary. Note that the first term on the right hand side of equation (5) is the lagged residuals from the levels relationships. We expect $\theta<0$ so that the GCC interest rate adjusts to restore equilibrium and higher the size of $\theta$, speedier is the adjustment. The estimate of $b$ indicates the extent of the monetary autonomy. For example $b=1$ would imply no autonomy at all.

\section{Data and Empirical Results}

\subsection{Data}

Two comparable interest rates data between the GCC countries and the US are used. They are short-term money market rates (overnight interbank rates) and short-term Treasury-bill rates. The availability of interest rates data for the GCC countries is problematic. Saudi Arabia and the UAE are excluded because long-term interest rates series are not available for these two countries. Quarterly data are used though, as explained in Obstfeld et al. (2004), annual data are preferable because the difference specification (3) is less problematic for annual data. The money market rates (MMR) or Treasury-bill rates for Oman and Qatar are not available before 2004. Using annual data would make the sample size small for individual country results. The Federal Funds rate (FFR) and US Treasury-bill rate are taken from the website of FED. For Bahrain the money market rates for the period 1990:1 - 2011:2 and Treasury-bills rates for the period 1991:1 - 2014:3 are used based on availability of data. Data are taken from International Financial Statistics (IFS). Treasury-bill rates for Kuwait discontinued after 2005 and money market rates are used for the period 1993:1 - 2015:4. These data are taken from either IFS or Central Bank website of Kuwait. Treasury bills rates for Oman and Qatar are not available at all. Money market rates for Oman are used for the period 2004:1 - 2015:4 and taken from IFS (latest data) and from the Central Bank of Oman website. Money market rates for Qatar are used for the period 2004:3 2015:4 and taken from IFS (latest data) and from the Central Bank of Qatar website.

\subsection{Empirical Results}

Before examining regression results, interest differentials between the US and the GCC countries are plotted in figure 1. It shows that the money market rate of Bahrain discounted after 2011:2 and the missing data of the Treasury-bill rate of Kuwait. Figure 1 shows that the money market rates of Bahrain and Kuwait followed closely to the Federal funds rate till the culmination of the global financial crisis in 2008 when observed differences are substantial. Since then spread was substantial. The money market rates of Oman coincide with FFR after 2008. The money market rates of Qatar seem did not follow at all the FFR starting from 2008.

Equations are estimated using individual country data and a panel of three or four countries depending on the availability of data. Since the data are differenced, we expected no problem of serial correlation. However, the D-W statistics from preliminary estimates indicates otherwise. Thus for individual country estimates the Newey-West heteroskedasticity and autocorrelation consistent (HAC) standard errors are reported. For panel data we have used cross-section SUR that corrects both cross-section heteroskedasticity and autocorrelation. These results are presented in table 2 .

Treasury-bill rates are available only for Bahrain and Kuwait (though discontinued after 2005 ). The estimates of $\beta$ are higher for treasury-bill rates compared to the money market rates. The estimate of $\beta$ for Bahrain is 0.90 which is highly significant and $R^{2}$ is also high. For treasury-bill rate of Bahrain we cannot rule out the trilemma. Estimates using money market rates are also quite high (0.74 and 0.76 for Bahrain and Oman, respectively) and they are highly significant. Estimates of $\beta$ for Kuwait are little smaller than other GCC countries. This is also consistent with the composite exchange rate arrangement by Kuwait. The most surprising result is obtained for Qatar. Initial estimate showed D-W statistic equal to 1.09 indicating the presence of serial correlation and the coefficient was significant $1 \%$ level. With the correction of serial correlation (with HAC option), it is not significant at any standard level. Looking at figure 1 for Qatar, we see that the MMR for Qatar followed the FFR very closely till the financial crisis of 2007-08. After the fourth quarter 2008 the MMR drifted away from the FFR, thus it is not surprising that the significant relationship is broken. There is no much difference in results of panel regressions. The estimated $\beta$ and $R^{2}$ are bit higher with the three countries panel 1 with more recent data. 
The results for Qatar are interesting and deserve special attention. These results put doubts on categorizing Qatar as open country (by Fernandez et al., 2015) with little capital control (in which case we expected estimated $\beta$ and $R^{2}$ higher than Bahrain and Kuwait and close to 1). The value of estimated $\beta$ is not only smaller than other countries, but more importantly it is statistically insignificant. Results (and figure 1 for Qatar) indicate that though the GGC countries have liberal capital flows, they can maneuver their interest rates if it is required as Qatar did after financial crisis. That is, they can exercise monetary autonomy when needed.

The cointegration results based on equation (4) are presented in table 3. The lag length of these equations are chosen based on adjusted $R^{2}$, Akaike information criteria (AIC), and Schwartz Bayesian criteria (SBC). The presence of second order serial correlation is performed using the Lagrange multiplier (LM) test. All F- statistics (except for the treasury-bill rate for Kuwait) reported in table 3 are greater than $5 \%$ or $1 \%$ upper bound $I(1)$ critical values (depending on the number of observations). These critical values are taken from Narayan (2005, Case III, p.1988) because of the small number of observation especially for Oman and Qatar. Thus, there is a long-run relationship between the federal funds rate and money market rates of the GCC countries. 

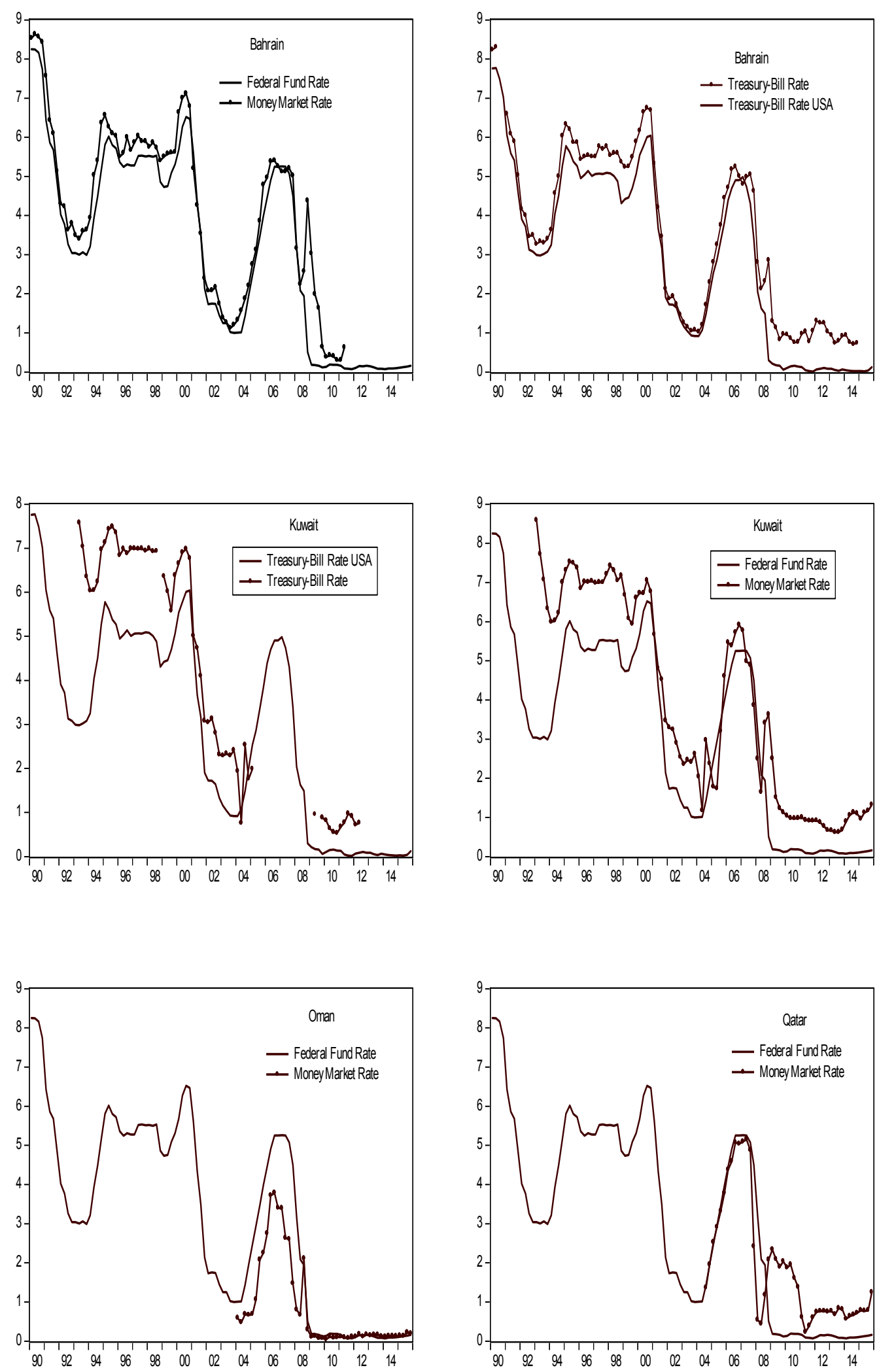

Figure 1. GCC and U.S. interest rates 
Table 2. Results of difference regression

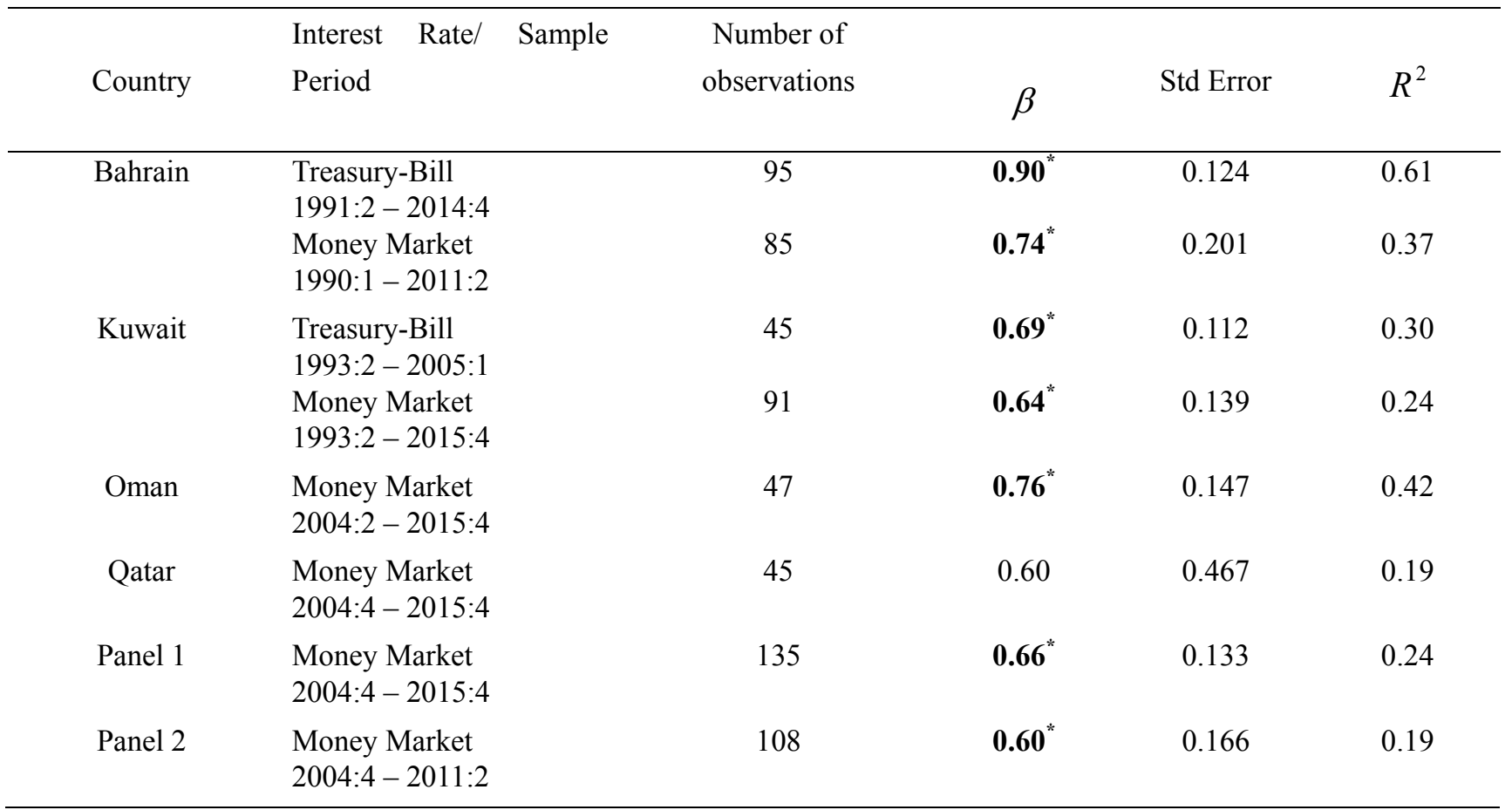

Note: * indicates significant at 1\% level, Panel 1 includes panel data of three countries Kuwait, Oman, and Qatar, and Panel 2 includes panel data of four countries Bahrain, Kuwait, Oman, and Qatar.

Table 3. Cointegration test results

\begin{tabular}{|c|c|c|c|c|c|}
\hline Country & $\begin{array}{l}\text { Interest Rate/ Sample } \\
\text { Period }\end{array}$ & $\begin{array}{c}\text { Number of } \\
\text { observations }\end{array}$ & Lag & LM (2) & $\mathrm{F}$ \\
\hline \multirow[t]{2}{*}{ Bahrain } & $\begin{array}{l}\text { Treasury-Bill } \\
\text { 1991:2 - 2014:4 }\end{array}$ & 94 & 1 & $0.17(0.84)$ & $6.83^{*}$ \\
\hline & $\begin{array}{l}\text { Money Market } \\
\text { 1990:1 - 2011:2 }\end{array}$ & 83 & 2 & $1.88(0.16)$ & $8.86^{* *}$ \\
\hline \multirow[t]{2}{*}{ Kuwait } & $\begin{array}{l}\text { Treasury-Bill } \\
\text { 1993:2-2005:1 }\end{array}$ & 43 & 1 & $0.62(0.52)$ & 4.53 \\
\hline & $\begin{array}{l}\text { Money Market } \\
\text { 1993:2 - 2015:4 }\end{array}$ & 89 & 2 & $0.73(0.49)$ & $9.36^{* *}$ \\
\hline Oman & $\begin{array}{l}\text { Money Market } \\
\text { 2004:2 - 2015:4 }\end{array}$ & 45 & 2 & $1.54(0.23)$ & $8.78^{* *}$ \\
\hline Qatar & $\begin{array}{l}\text { Money Market } \\
\text { 2004:4-2015:4 }\end{array}$ & 44 & 1 & $0.39(0.68)$ & $9.40 * *$ \\
\hline
\end{tabular}

Note: ${ }^{*}$ Indicates above $5 \%$ upper bound $I(1)$ critical value and ${ }^{* *}$ indicates above $1 \%$ critical value.

These results are corroborated with the estimates of equation (5) which are reported in table 4. The estimates of $b$ are quite high (and consistent with results in table 2) for Bahrain, Kuwait, and Oman. Though there is a long-run relationship between the federal funds rate and money markets rate of Qatar, the short-run level relationship is not significant. The estimates of $b$ and the speed of adjustment $(-1.14)$ for Oman indicates Oman has no autonomy at all. The average adjustment speed for Kuwait is -1.14 which means whatever little deviation it has, it will be restored fully within the quarter. The average adjustment speed for Bahrain is -0.78 which means $78 \%$ will be restored within the quarter. 
Table 4. Estimates of equation (5) with money market rates

\begin{tabular}{ccccc}
\hline & Bahrain & Kuwait & Oman & Qatar \\
\hline Number of observations & 83 & 88 & 45 & 43 \\
$b$ & 0.64 & 0.73 & 1.25 & 0.46 \\
t-stat & 5.58 & 6.50 & 3.96 & 2.02 \\
$\theta$ & -0.78 & -1.12 & -1.14 & -0.79 \\
t-stat & -4.39 & -4.25 & -3.96 & -3.0 \\
LM (2) & 1.95 & 0.14 & 0.23 & 0.02 \\
Sig. & 0.15 & 0.87 & 0.80 & 0.98 \\
\hline
\end{tabular}

\section{Conclusion}

The extent of capital controls is an important element of the effectiveness of the monetary policy of an open country. Proponents of trilemma argue that the countries with fixed exchange rates face an unpleasant situation because they can either choose monetary autonomy or free cross-border capital movement; they cannot choose both. The GCC countries have maintained the fixed exchange rates for a long period of time and they have liberal (not completely open) capital control. However, proponents of trilemma maintain that whether partial or no capital control at all would have the same consequence.

The recent IMF's AREAER shows that Bahrain, Oman, Qatar, and the UAE have the similar measure of capital controls whereas Kuwait and especially, Saudi Arabia have little more control measures in place. However, these measures are still within the paradigm of liberal capital controls. Given this one would expect that the GCC countries would have similar (or no) monetary autonomy. We test this for the GCC countries excluding Saudi Arabia and the UAE due to data unavailability. Availability of data also has forced us to limit results for Oman and Qatar for recent episode from 2004 to 2015.

Results show, in conformity of trilemma, that Bahrain and Oman have some (more or less) monetary autonomy if we prefer the difference estimates. Kuwait has been enjoying some short-run monetary autonomy probably due to its currency basket exchange rates arrangement; however, the average speed of adjustment is quite high (fully adjusted within the quarter).

The most interesting result is obtained for Qatar. The money market rate of Qatar followed quite closely to the federal funds rate till the financial crisis of 2007-08. Since then Qatar did not follow the federal funds rate at all. Results show no difference and levels relationship between Qatar and the US interest rates even though some studies have classified Qatar as open economy in the context of capital control. It is relevant to mention that during 2003 - 2008 Qatar experienced highest inflation among all the GCC countries which forced Qatar to take stand on interest rate (monetary) policy to stabilize price level and it succeeded. This results show the GCC countries can maintain higher interest rates relative to the US interest rates without attracting capital flows. As such these results contradict the recent findings of Klein and Shambaugh (2015) that countries cannot round the corners of the policy trilemma by partial capital control to establish full monetary policy autonomy.

\section{References}

Abed, G. T., S. N. Erbas, S. N., \& Gueromi, B. (2003). The GCC monetary union: Some considerations for the Exchange Rate Regime, IMF Working paper WP/03/66, Washington, DC.

Fasano, U. (2003). Monetary union among member countries of the Gulf Cooperation Council, Occasional paper 223, IMF, Washington DC. https://doi.org/10.5089/9781589062191.084

Fernandez, A., Klein, M. W., Rebucci, A., Schindler, M., \& Uribe, M. (2015). Capital control measures: A new dataset, IMF WP/15/80, Washington DC.

Frankel, J. A., Schmukler, S. L., \& Serven, L. (2004). Global transmission of interest rates: Monetary independence and currency regimes, Journal of International Money and Finance, 23(5), 701-34. https://doi.org/10.1016/j.jimonfin.2004.03.006

Hasan, M., \& Nakibullah, A. (2015). Price Level and Inflation in the GCC Countries, International Review of Economics and Finance, 39, 239-252. https://doi.org/10.1111/twec.12056

Hassan, K., Nakibullah, A., \& Hassan, A. (2013). Sterilization and Monetary Control by the GCC Member Countries, World Economy, 36, 1566-1587. http://dx.doi:10.1111/twec.12056.

Klein, M. W. (2012). Capital controls: Gates versus walls, Brookings Papers on Economic Activity, 2012(1), 317-355. 
https://doi.org/10.1353/eca.2012.0015

Klein, M. W., \& Shambaugh, J. C. (2015). Rounding the corners of the policy trilemma: Sources of Monetary Policy Autonomy, American Economic Journal: Macroeconomics, 7(4), 33-66. https://doi.org/10.1257/mac.20130237

Nakibullah, A. (2011). Monetary policy and performance of the oil-exporting Gulf Cooperation Council countries, International journal of Business and Economics, 10(2), 139-157.

Narayan, P. K. (2005). The saving and investment nexus for China: Evidence from cointegration tests, Applied Economics, 37(17), 1979-1990. http://dx.doi.org/10.1018/00036840500278103.

Obstfeld, M., Shambaugh, J. C., \& Taylor, A. M. (2004). Monetary sovereignty, exchange rates, and capital Controls: The trilemma in the interwar period, IMF Staff Papers, 51, 75-108. https://doi.org/10.3386/w10393

Obstfeld, M., Shambaugh, J. C., \& Taylor, A. M. (2005), The Trilemma in history:Trade-offs among exchange rates, monetary policies, and capital mobility, Review of Economics and Statistics, 87(3), 423-438. https://doi.org/10.1162/0034653054638300

Obstfeld, M., Shambaugh, J. C., \& Taylor, A. M. (2010). Financial stability, the trilemma and international reserves, American Economic Journal: Macroeconomics, 2(2), 57-94. https://doi.org/10.1257/mac.2.2.57

Pesaran M.H., Shin, Y., \& Smith, R. J. (2001). Bounds testing approaches to the analysis of level relationships, Journal of Applied Econometrics, 16, 289-326. https://doi.org/10.1002/jae.616

Shambaugh, J. C. (2004). The effect of fixed exchange rates on monetary policy, Quarterly Journal of Economics, 119(1), 301-352. https://doi.org/10.1162/003355304772839605

\section{Copyrights}

Copyright for this article is retained by the author(s), with first publication rights granted to the journal.

This is an open-access article distributed under the terms and conditions of the Creative Commons Attribution license which permits unrestricted use, distribution, and reproduction in any medium, provided the original work is properly cited. 